\title{
A case study of a Turkish vocational high school, and the challenges for teachers
}

\author{
Ahmet Ayaz (D) and Nurten Karacan Özdemir (D) ${ }^{\mathrm{b}}$ \\ aDepartment of Psychological Counselling and Guidance, Hasan Kalyoncu University, ahmet. \\ ayaz@hku.edu.tr, Gaziantep, Turkey; ${ }^{b}$ Department of Psychological Counselling and Guidance, \\ Hacettepe University, karacan.nurten@gmail.com, Ankara, Turkey
}

\begin{abstract}
This case study reports on challenges and professional perspectives of vocational high school teachers working in a socially disadvantaged in rural Turkey. The data were gathered from 14 participants, including teachers, administrators and counsellor through individual and focus group interviews and classroom observations. The analysis found that students in Turkish vocational high schools are negatively positioned, this was evidenced in poor student engagement and the struggles of classroom management experienced by teachers. The perceived problems and needs showed some differences across teachers who provide academic and vocational courses. The findings imply that there is a need for social justice advocacy for rural vocational high school students by fostering teachers and improving the system by policy development.
\end{abstract}

\section{ARTICLE HISTORY}

Received 21 May 2020

Accepted 19 February 2021

\section{KEYWORDS}

Technical and vocational training and education; teacher needs; professional issues

\section{Introduction}

Technical and vocational education and training (TVET) institutions were established to meet the need for qualified intermediate staff (Sarkees-Wircenski and Scott 1995) who have practical knowledge and skills related to a particular job (Hayward and Benson 1993; Plank, DeLuca, and Estacion 2008; United Nations Educational, Scientific and Cultural Organization (UNESCO) 2012). Thus, to train qualified personnel, it has become necessary to develop cooperation between the schools and industry (Rojewski 2002). Along with economic and industrial revolutions, the educational content of TVET needs to be revised because of changing expectations from employees (Hawke 2000; Lewis 1998). For instance, it was underlined that Industry 4.0 affected the required skills and abilities from employees (Benešová and Tupa 2017) such as creativity, problem-solving skills, using high-technology and having digital literacy (Karacan-Ozdemir and Ayaz

CONTACT Ahmet Ayaz ahmet.ayaz@hku.edu.tr

Author Note: We have no conflicts of interest to disclose.

Correspond concerning this article should be addressed to Ahmet Ayaz, Hasan Kalyoncu University, Education Faculty, Gaziantep Airport Way, 8.km. Email: ahmet.ayaz@hku.edu.tr 
2020), which should be also developed through TVET has an essential role on growing a well-qualified workforce (Pfeiffer 2015). Similarly, today's TVET graduates are expected to have some skills such as teamwork, communication, ethical/social responsibility, analytical thinking, professionalism, technical knowledge, reading comprehension, critical thinking, problem solving, creativity and innovation (American Management Association (AMA) 2019; National Association of Colleges and Employers (NACE) 2017), referring to soft and transferable skills (Lynch 2000; Plank, DeLuca, and Estacion 2008).

Lynch (2000) found four themes for improving vocational education in the literature: (a) integrate career planning activities into the curriculum, from pre-K to lifelong learning; (b) improve career and technical programmes in high schools through a broader reform; (c) reform vocational education for upgraded career and technical education; and (d) prepare and support students both for workplaces and continuing education. This model, which combines theoretical and applied education, increases both employability and earnings of students (Bishop and Mane 2004; Dania, Bakar, and Mohamed 2014). At this point, TVET teachers have critical roles as a team leader, a supervisor, an inspiring person, rather than a standard instructor (Viviano 2012). In other words, teachers should support students both in academic field with innovative teaching methods and in labour market skills (Bottoms and McNally 2005; Grollmann 2008). According to National Board for Professional Teaching Standards (NBPTS) (2017), vocational high school teachers are expected to be competent in recognising students, teaching principles, specialisation in the field, assessment, and evaluation to foster both their own professional development and the development of their students. Moreover, teachers should develop social skills of students to ease the transition to working life by creating new networks. Furthermore, teachers are expected to mentor students in internships to reflect their qualified education and field practices to students, thereby helping students create a projection for the future and make the teaching process permanent (Jacques and Potemski 2014; Viviano 2012).

\section{Vocational high schools in Turkey}

There are 4640 vocational high schools with up to 1.8 million students in Turkey, which is a very important area in Turkish Educational System (Turkish Ministry of National Education (MoNE) 2018a). Vocational high school students are trained to work in 228 different professional fields (International Centre for Technical and Vocational Education and Training (UNECOV) 2013). Students who successfully complete primary and secondary education (lasts in eight years) and pass a nationally centralised exam can study at vocational high schools. Vocational high schools offer a-four years education: a common national curriculum in the first year ( $9^{\text {th }}$ grade), courses relevant to vocational field selected in the second year $\left(10^{\text {th }}\right.$ grade) and their specialisation in the third year $\left(11^{\text {th }}\right.$ grade), and 
apprenticeships programme in the last year $\left(12^{\text {th }}\right.$ grade). Vocational high school graduates can continue into polytechnic colleges in two-year programmes without entering any exam, or can pursue to a related four-year tertiary education by succeeding university entrance exam at the national level (Turkish Ministry of National Education (MoNE) 2018a).

Turkey has made enormous effort for improving TVET at high school level; has focused on developing occupational standards that are used for developing modules for vocational education and launched curriculum reform (European Center for the Development of Vocational Training (Cedefop) 2019). Turkey, following the technological transformation process with the motto of 'Digital Transformation' (Republic of Turkey Ministry of Industry and Technology 2018), has the potential to meet the need for intermediate staff through vocational schools. It was underlined that vocational education should be adapted to this digital transformation (Bozgeyikli 2019) and respond to the requirements of Industry 4.0 (Özer 2018). Accordingly, the promotion of vocational high schools, the development of capacity, to ensure cooperation with industry and to support vocational schools teachers' development occupies an important place within the educational policies of Turkish Republic Presidential Strategy and Budget 2019; Turkish Ministry of National Education (MoNE) 2018b). Thus, especially the role of teachers becomes more important in adapting to the changing economic structure and industrial system in Turkey (Çınar, Döngel, and Söğütlü 2009). Although job satisfaction in the vocational high school teachers in Turkey is on a moderate level (Girgin and Demir 2017), the previous work addressed some problems such as students' indifference to the lessons and discipline problems, lack of physical facilities and intense education program (Çavuşoğlu and Savaş 2016; Çiçek Sağlam and Dönmez 2016; Dağ 2018; Peker and Kaygusuz 2009; Tamer and Özcan 2014; Toytok and Yıldırım 2018; Tunç, Yıldız, and Doğan 2015) and indicated that these decrease teachers' job satisfaction and increase their occupational burnout (Avşaroğlu, Deniz, and Kahraman 2005). In addition, TVET in disadvantaged areas like rural settings in Turkey mean that is a lack of opportunities, resources and services and this necessitates a focused approach that includes social justice.

Considering the duties and responsibilities of vocational high school teachers, it can be seen that they have a key role in students' access to education and employment (Lynch 2000; Miller 1984), particularly for those who live in rural areas with economical disadvantages as geographical and economic conditions might affect access to education negatively (Wheelahan and Moodie 2016). Sen (2009) underlined the crucial role of education to develop and foster abilities of individuals, which would improve independence of people, eventually from the perspective of social justice in education. At that point, it is important if individuals have equal opportunities to access resources to enhance their abilities, implying social justice in education (Nussbaum 2011). However, TVET in disadvantaged rural areas might be more challenging because 
of more difficulties or any other kind of oppression as well as few opportunities, resources, and services, which requires advocating for organisational and systemic change, implying need for social justice (Arthur 2005).

Social justice means that people have a right to utilise the resources and the benefits of society equally (Miller 2001). It is critically important in educational settings that have fundamental distributive roles such providing learning opportunities as well as socialisation experiences, which affect students' academic, social, and career life (Resh and Sabbagh 2016); thus provides a theoretical basis for the current study. TVET plays important role to bring social justice to socioeconomically disadvantaged rural areas by providing educational opportunities to develop students' skills for the world of work, which can help them to be employed (Gautam, Poudel, and Paudel 2018; Vandekinderen et al. 2018). TVET has a potential to reduce poverty in those regions by improving students' academic and occupational skills and thus increasing the possibility for employment (Alcock 1997), which means promoting social justice (Gautam, Poudel, and Paudel 2018). However, despite the crucial roles of TVET in providing social justice, less systematic attention has been focused on the examination of challenges of TVET in socioeconomically disadvantaged areas from the perspectives of teachers, which is the main aim of the current study.

Considering the fact that students in rural areas mostly attend vocational high schools in Turkey (Turkish Ministry of National Education (MoNE) 2019), and within the framework of social justice, given the role of teachers of these students on information and access to employment, it is important to determine the problems faced by teachers working in these areas and their needs in detail. Thus, this study aimed to reveal the problems faced by vocational high school teachers in a rural area in Turkey and their professional development needs through the perspectives of the teachers giving academic and vocational courses, school administrators and school counsellors. With this purpose, this study sought to answer the following questions: 1) What are the problems perceived by the teachers who teach academic and vocational courses in a rural vocational high school? 2) What are the professional development needs of these teachers?

\section{Methods}

This study used case study design, as an in-depth study of complex situations that require extensive and in-depth analysis using multiple data sources (Merriam 1998; Yin 2018).

\section{Study group}

The study was conducted in a socioeconomically disadvantaged rural vocational school in Gaziantep city, which has the highest unemployment rates nationally (Turkish Ministry of National Education (MoNE) 2018a), located in Eastern 
Turkey. The school that the data are collected from serves a mobile teaching, which means that students who live in remote villages where there is not any school have to arrive at school by distance transportation provided by the government. The study group included four academic course teachers (English, Turkish Language and Literature, and History), five vocational course teachers (Electricity, Child Development and Education, and Information Technologies), four school administrators, and one school counsellor $(50 \%$ women, in total), by using maximum diversity sampling method to take indepth information from different sources (Patton 2014).

\section{Data collection}

Individual and focus group interviews were conducted to obtain detailed information about the difficulties experienced by teachers in the school, ways to overcome difficulties, their strengths and areas in which they need support. The sample questions included: What are the difficulties and the sources of these difficulties you have at your school? What are your ways to overcome these difficulties? In which areas do you need support as a teacher in the process of improving your school? Interview summary and first impression form was used to obtain information about interview process and the first impressions of the researcher after the interview. Class observation form was used to collect data from teachers' classroom practices using participant observation technique.

Prior to the data collection process, informed consent was obtained by the participants. Next, separate focus group interviews were conducted with school administrators, the teachers who teach different academic and vocational courses at the school, consecutively. Then, an individual interview was conducted with the school counsellor. Following, classroom observations were done, considering, the criteria of participating in focus group interviews and having one of them in academic and the other in vocational courses for the selection of teachers to be observed by informing the teachers about the purpose of the observation and how to perform it.

For trustworthiness of the study, triangulation, using multiple methods or data sources in qualitative research (Patton 2014; Yin 2018), was used to collect the data from school administrators, school counsellor, and teachers who teach vocational courses and academic course by using semi-structured interviews, focus groups, and classroom observations. Long-term interaction and observation (Creswell 2012) were established by that researchers who took part in educational studies and projects for teachers and students between 2016 and 2019 in this district. A meeting was conducted to check and verify the accuracy of the findings with participants (Creswell 2012; Miles and Huberman 1994), which established a chain of evidence (Yin 2018), also. A rich and detailed description (Creswell 2012; Miles and Huberman 1994) was provided by filling the forms after interviews and classroom observations. 


\section{Results}

For data analysis, the researchers followed the steps of coding, obtaining themes, reviewing themes and completing the findings (Yıldırım and Şimşek 2016). Interpretive content analysis (Gall, Gall, and Borg 2014), the process of obtaining meaningful structures from the parts of the text in the revealing of codes and themes, was used. Prior to analysis, all audio-recorded interviews were transcribed verbatim. Next, the data obtained from the interviews and observations were transferred to MaxqDa12, a qualitative data analysis program, to make the data prepared for analysis. Then, the researchers conducted the first coding together to obtain a common perspective on data analysis procedure and the remaining independently. After the researchers completed the coding, they came together, discussed the codes and themes, and finalised them to be reported.

The findings were presented under two main categories: (a) problems perceived by teachers, including student-related, socio-cultural and systemrelated problems (b) professional development needs of teachers within the perspective of social justice in education. As can be seen in (Figure 1), the lack of interest and motivation of students among students-related problems was perceived by both teacher groups. However, the teachers teaching academic courses emphasised low self-efficacy belief and low academic achievement of students, only. Although the problems resulted from the socio-cultural structure were perceived in both groups of teachers, teachers who teach academic courses felt this problem more intensely. Teachers who give vocational courses put more emphasis on the problems resulted from the education and curriculum applied in vocational high schools as well as the administrative processes under the system-related problems, yet both groups emphasised infrastructure problems with similar frequency. Regarding professional development needs, vocational course teachers stated their needs for following technological developments in the field mostly, academic course teachers mentioned their needs regarding classroom management, contemporary teaching methods and having a vision of vocational high school prominently. In sum, it could be said that the problems regarding students' low motivation or success, socio-cultural structure or academic curriculum emphasised by teachers indicate social justice advocacy for TVET students and professional development needs of teachers imply the way to decrease social injustice in vocational education in rural areas.

\section{Vocational high school teachers' perceived problems}

\section{Student-related problems}

Lack of Interest and Motivation: The teachers expressed students' indifference to the lessons as the most intense problem. In this regard, K6 said, 'No matter how important the lesson is, the student lays his head and sleeps even in the lesson 


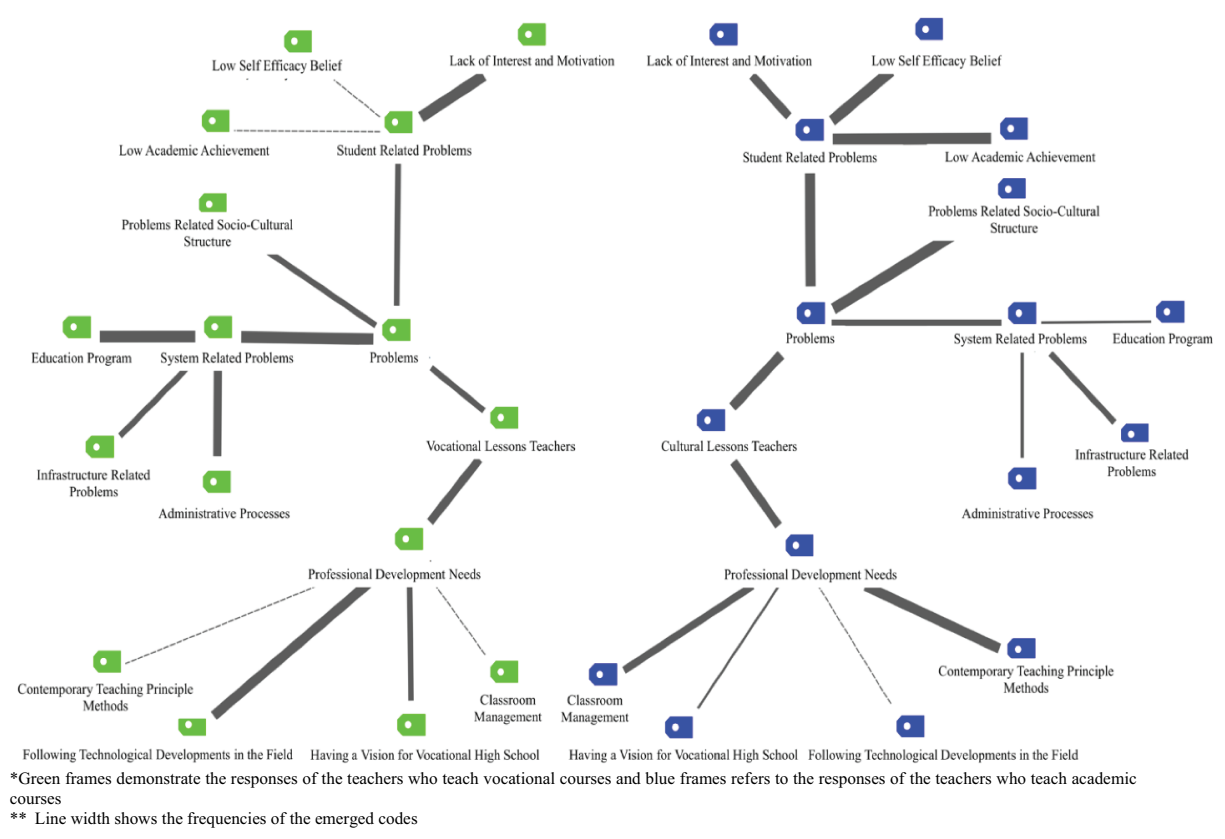

Figure 1. Problems and professional development needs of teachers giving vocational and culture courses

he knows he will fail.' K9 underlined that ' ... they are not even aware of what the name of the course is supposed to be'. According to the teachers, this indifference can be explained by the lack of intrinsic motivation among students. For example, K5 said, 'I don't think students have a goal that they take seriously' K1 states that this understanding leads to the idea of 'just getting a diploma and graduating.' Similarly, school administrators emphasised that students did not care about their future due to lack of interest and motivation.

Low Self-Efficacy Belief: The teachers stated that the students come to vocational high schools with the thought of 'we will not succeed, we cannot do it' (K3). It has been stated students who have accepted this belief do not engage in a planning for their future. For instance, K10: ' ... we are talking about what are our goals, I cannot do that, I cannot win that university, that is, they are mostly lack of self-confidence.' K2 stated that the conversations with the students include the phrases like that 'usually I cannot do it, I cannot succeed'.

Low Academic Achievement: Another theme was about low academic achievement of students. K4 mentioned, 'We try to explain abstract issues to children who almost cannot perceive concrete'. K3 expressed this situation as 'they cannot read, they cannot write, I take notes, I read, I do, they cannot do anything, in this sense I have a lot of problems'. School administrators, like teachers, mentioned that the academic success of vocational high school students is low. 


\section{Problems related to socio-cultural structure}

Teachers mentioned socio-cultural structure as another problem area such as early marriages. K4 said, 'When they realise that they cannot go to university, they see the way of getting out of their environment (the region they live in) as a marriage.' Furthermore, K1 pointed out that early marriages were seen in both female and male students and they were culturally encouraged. K10 added that 'Families, neighbours, and society have given up on them; they have no expectations about their future.'

\section{System-related problems}

System-related problems expressed by teachers emerged as the structure of the education program implemented in vocational high schools, infrastructure problems, and problems arising from the education system.

Education Program Implemented in Vocational High Schools: The teachers stated that the education program implemented in vocational high schools is quite intense and this affects the education and training process negatively. For example, K6 expressed that, 'Lesson hour is too long, the student is tired in academic lessons and rests in vocational courses' Moreover, K10 underlined that the amount of lessons, as 10 hours per day, exhausts students and the high number of lessons causes short breathing intervals and this causes students not having time to rest. To overcome this problem, K8 stated that the curriculum should be updated by reducing the number of lessons and that this update should be made in accordance with the developmental characteristics of the age group as well as in the light of technological developments.

Infrastructure Related Problems: Having no internet connection was one of the primary problems related to the infrastructure experienced by teachers. K4 stated, 'In our school, for example, these [smart] boards for 4 years, but we do not have internet'. The internet connection problem, which was also seen in the classroom observations, disrupted the teaching of the teachers and they had been using their own mobile data as a solution.

Problems Related the Administrative Processes: Under this problem, it was noted that students who are not successful in other schools are transferred to vocational high schools with the understanding that vocational high school is easy (K2). Another problem was emerged as looking at the university entrance rate of students as a criterion of school success. K1 said, 'Our school generally interprets the achievement of university entrance as a success'. This finding was also revealed during the meeting with the school administrations who stated that school success can be achieved by acquiring students' earning some academic majors in universities such as medicine and engineering. 


\section{Professional development needs of vocational high school teachers}

\section{Classroom management}

Teachers' difficulties in conducting classroom management were demonstrated by the interviews by both groups of teachers, school administers, and school counsellor, and classroom observations. K4 expressed this difficulty as 'It causes us to shout all the time in the classroom, we are tired in this sense and we are getting tired at the point of teaching, so I think.' K1 states that classroom management can be achieved by creating an environment of fear and oppression on students. K6 said, 'I cannot draw the attention of children to the lesson.' These findings referred to the professional development needs of teachers in ensuring classroom management. School administrators also emphasised the needs of teachers regarding classroom management, mentioning especially those who are in the first years of their profession; needed to improve themselves on this issue. Moreover, it was observed that the students spent the course process by talking to each other and sitting scattered in the classroom through the classroom observation process by researchers.

\section{Contemporary teaching principle methods}

The classroom observations yielded that teachers varied in the extent to which they used innovative teaching methods and techniques. For example, it was observed that the teacher used didactic training for 40 minutes and the students' interests and attention were distracted. On the other hand, in another lesson observed, it was seen that the teacher used the creative drama method and the students actively participated in the lesson and their attention was not distracted. This situation indicates the relationship between teaching methods and techniques and classroom management. It could be said that there was a need for professional development opportunities in innovative teaching methods and techniques especially for teachers who have difficulties in classroom management.

\section{Following technological developments in the field}

The teachers stated that they should follow the technological developments in the world, but they could not do this adequately. It was observed that this need was more pronounced especially in teachers who gave vocational courses. $\mathrm{K} 7$ stated, 'I can tell from my point of view, we have to follow the sector but we cannot do it'. K6 said, 'The teacher should be able to follow the fairs right now ... but we have no opportunity to do this.' It was observed that teachers have expectations for planning and organising travel programs for their professional development by the MoNE at national level. For example K9 said, "The teacher also dulls ... The MoNE should take teachers to certain fairs in Turkey at least ". 


\section{Having a vision for vocational high school}

As a result of both interviews with the school administrators and teachers and the observations made by the researchers, it was seen that administrators aimed not to train students as a well-trained intermediate staff, indeed expected them to gain other undergraduate programs in a university. Similarly, teachers emphasised the same thing; for instance, K6 stated, 'I say, study in a university, do what you want to do after that'. Similarly, K7 'Our children want to learn life at a high school age, so they try to start their lives right after high school ends'. They all implied a need for having a vision for vocational high school.

\section{Discussion}

\section{Vocational high school teachers' perceived problems}

According to the findings, the problems perceived by vocational high school teachers were classified under three themes as student, system, and sociocultural structure-related problems. Social justice requires being able to understand big picture (Hooley and Sultana 2016), like the current findings provided. The results supported the fact that environmental and societal context should be considered for practicing social justice (Arthur and McMahon 2005). Firstly, the 'lack of interest and motivation of the students', which was one of the student-related problems, was emphasised by teachers who give academic and vocational courses as well as school counsellor and administrators. This problem was expressed as that students considered the education they received was meaningless, and avoided imagining and planning their future. Supportively, Ayonmike, Okwelle, and Okeke (2015), reported students' lack of interest was an important problem in vocational high schools. At that point, it could be seen that the role of teachers in eliminating the loss of interest and motivation of students (Spöttll 2009) and the need to gain students' learning to learn perspective (Lynch 2000) was emphasised.

The findings also inferred that students' lack of interest and motivation caused problems in the classroom. Similarly, it was emphasised that the lack of interest of students resulted in classroom management difficulties and conflicts between teacher and students (Buthelezi 2018), which in turn loss of motivation in teachers (Garisch 2007). 'Low self-efficacy belief and low academic achievement' in students emerged as the other themes were mostly expressed by academic course teachers and school counsellor, consistently with the literature (e.g., Murgor 2013). It could be tentatively assumed that this might be a result of teaching only academic courses at the $9^{\text {th }}$ grade in vocational high schools along with the common curriculum implemented in all high schools in Turkey, as aforementioned. Similar to this tentative assumption, Taş et al. (2013) argued that the curriculum of vocational high schools could overwhelm 
students, which might result in early school-leaving problem in Turkey. Accordingly, updating these curricula was among the strategic goals of the Turkish Ministry of National Education (MoNE) (2018b). Özer (2018) suggested to review this outdated curriculum align with the requirements and demands of industry. It could also be said that the students' desire to start vocational education as soon as possible and see the academic lessons as unnecessary trigger the lack of interest and motivation. Accordingly, the relevant literature underlined that the academic failure of students in vocational high schools might be an important risk factor for early school leaving (Plank, DeLuca, and Estacion 2008). On the other hand, the critical role of teachers and parents on the development of self-efficacy beliefs of vocational high school students was noted (Spöttll 2009). Furthermore, it was mentioned that while fostering their interest and motivation in education would strengthen their bonds to the education process (Omar et al. 2019), increasing students' self-efficacy beliefs would positively affect their career planning (e.g., Ali and Marwan 2019; Raymond et al. 2018). These all implied the need to review the existing curriculum and the relevant policies in this regard to foster students' self-efficacy beliefs as well as interest and motivation to the education, connected to their interests and intentions for coming to vocational high school, which would be socially just approach teaching and engaging the students. Moreover, these results inferred the necessity of empowering role of education on promoting the abilities of disadvantaged students for justice as mentioned by Sen (1999).

Problems arising from socio-cultural structure constituted another problem area perceived by both teacher groups. The findings displayed that vocational high schools were perceived like that problematic students go there, academic success was insignificant and it was easy to graduate from them by the society, consistently with the previous work (e.g., Kennedy, Udoetuk, and Ufot 2017; Lamb 2011). Similarly, the relevant literature addressed that families think that vocational high schools do not offer a future to their children (Ismail and Abiddin 2014), the society see these schools where socioeconomically disadvantaged students (Oketch 2007) or students with the potential to harm society go (Buthelezi 2018). The findings also showed that students in this vocational high school, which was located in a socioeconomically disadvantaged region, preferred options such as working in the field with their families or getting married at an early age instead of going to school. These findings were somewhat similar to the studies (e.g., Egun and Tibi 2010), which pointed out that female students were seen as an assistant in the work of families and their education was perceived as a loss of workforce, especially in agricultureoriented societies. In addition, the related literature underlined the role of sociocultural structure on the development of vocational high schools and in the solution of their problems (e.g., Ayonmike, Okwelle, and Okeke 2015; Lynch 2000). It could infer that the biases about vocational high school students and TVET in the society would limit educational and career alternatives of students, 
which is unjust (Sahlberg 2007; Özer 2019). Thus, all these findings implied the need for reforms on educational policies grounded on a vision of social justice (Hytten and Bettez 2011) to enhance the fame of vocational training in the society. This kind of policy development should consider supporting inclusion and equity, adopting a mission of high expectations for all students, building interactive relations with community, and reinforcing social justice education (Carlisle, Jackson, and George 2006).

The analysis revealed systemic problems, also. The teachers of vocational courses mentioned the intensity and outdatedness of the education and training curriculum implemented in vocational high schools, which was also seen as a reason for students' loss of motivation by mentioning the need for reducing the course load and renewing the curriculum in the light of current developments. These findings were consistent with previous findings, which indicated heavy course load (Buthelezi 2018) and outdated educational curricula were (Hassan 2010) in vocational high schools. At that point, the relevant literature underlined that teachers should update the curriculum they implement (Boesel and McFarland 1994) in accordance with students 'developmental characteristics and revealing students' strengths (Buthelezi 2018) and integrate career development programs into education programs (Lynch 1997, 2000). In Turkey, the studies carried out by the Turkish Ministry of National Education (MoNE) (2018a) on vocational high school course hours and curriculums showed that this need was perceived as a general problem and steps towards solution have been taken within the scope of policy development. Another systemic problem was related to the lack of infrastructure, such as the absence of an internet connection, emphasised by both groups of teachers and yielded in classroom observations, which was also underlined in the previous work (e.g., Kennedy, Udoetuk, and Ufot 2017). At that point, it was noted that the lack of material in schools disrupts the educational process (Ayonmike, Okwelle, and Okeke 2015; Buthelezi 2018; Lamb 2011) and the quality of the materials used by vocational high school teachers in the course will help students increase their participation and interest (Zulu and Mutereko 2020). Moreover, the elimination of infrastructure deficiencies in vocational high schools would accelerate the process of adaptation of graduates to the sector and positively contribute to employment (Oketch 2007). The last one was 'administrative problems', which were perceived more intensively by vocational course teachers and revealed in observations and with the interviews with school counsellor and administrators. In this context, the perception in society that vocational high school is a type of school where unsuccessful students go was reinforced by the education system in Turkey because of that the students who have failed at other types of schools were directed to vocational schools during interim period. Furthermore, it was observed that the rate of students' passing the university exam was seen as a criterion of school success by school administers, which was assumed to result in a pressure on the teachers, especially those who give academic courses. In 
sum, motivation problems of students that could be stemmed from the curricula that do not meet interests and needs of students as well as misjudgements about vocational high school students like that they are not good enough for academic schooling arise questions about socially just approaches in education.

\section{Professional development needs of vocational high school teachers}

According to the findings, it was observed that academic course teachers need professional development in the sense of classroom management, contemporary teaching methods, and having vision about vocational high school, and teachers who give vocational courses mostly about following technological developments in the field. Firstly, it is observed that academic course teachers needed classroom management skills to direct students' attention to the lesson and increase their motivation, as they mostly used didactic teaching methods, which resulted that distraction of attention and the occurrence of in-class problems. For this reason, these findings inferred to the needs of teachers to acquire knowledge and skills regarding contemporary teaching methods as well as classroom management. Similarly, the previous work addressed that vocational high school teachers were insufficient to use new teaching methods (Ayonmike, Okwelle, and Okeke 2015), yet teachers' classroom management skills increase students' interest in the lesson (Zulu and Mutereko 2020). On the other hand, the fact that this need was not a priority for the teachers who give the vocational lessons can be explained by the fact that these lessons are practical and the students participate in more lessons. At that point, vocational high school teachers should use innovative teaching methods (e.g., Abdullah et al. 2019; Kim et al. 2019), and especially young teachers should learn to combine theory and practice (Spöttll 2009). Finally, 'following the technological developments' was another prominent professional development need of the teachers, especially those who give the vocational courses as they wanted to integrate the concepts such as Digital Transformation and Industry 4.0 into their teaching, yet had infrastructural problems such as access to the Internet. The previous work showing that vocational high school should keep their professional development continuous (e.g., Spöttll 2009; Ismail and Hassan 2019) supported this finding, and it was suggested to obtain mentorship from those working in the sector in this regard (Mohamad, Saud, and Ahmad 2009). In addition, when teachers follow the technology, this will contribute to students' self-development and significantly increase their employability (Buthelezi 2018; Ismail et al. 2019). Herein, it was seen that teachers needed to gain a vision of vocational high schools as they considered that the students should enter university and be placed in an academic higher education program outside their own branches. Within the framework of the findings obtained from the interviews, it can be said that this expectation was reflected to the students and as a result of not being adopted by the students, it might have caused job 
dissatisfaction among the teachers. These results might address fundamental role of teachers to critically reflect on their personal qualities that improve social justice practices in education (Hackman 2005).

This study has some limitations. Firstly, the study was performed at one school, which limits the generalisability of the findings, although it is not the prerequisite in qualitative study. In fact, case study is aimed to be conducted on a specific subject, like exploring the problems and professional development needs of teachers in a socioeconomically disadvantaged vocational high school in a rural area in the current study. Moreover, multimethod data gathering method was used to overcome this limitation. The future studies could gather data from stakeholders of vocational high schools such as students, parents and employers to determine policy development needs in this field, more comprehensively.

\section{Conclusion}

This study contributes to comprehensively understand the issues that vocational high school teachers working with low-income students in rural areas face with, revealing implications for policy, practice and research. In addition, this study indicated that technical and vocational education and training (TVET) have not had sufficient interest and emphasis, even has relatively low status despite its crucial role, comparing general academic education, just underlined before (OECD 2010). Furthermore, lack of warranty of employment and lower education level of students indicates very particular problems of a specific group. Moreover, as revealed in this study, another challenge for TVET underlines its aim; educating students for low- or middle-skilled jobs, the jobs in this spectrum have been decreasing though (Wheelahan and Moodie 2016). Especially speaking of in low-income vocational schools, they might experience more difficulties or any other kind of oppression as well as have or reach few opportunities, resources, and services, as shown in the current study, comparing with others, which implies advocating for organisational and systemic change (Arthur 2005). Thus, the main implication of the present study addressed need for social justice for these students by supporting the teachers as well as improving the system. This indicated the cruciality of the roles and responsibilities of policy makers in this regard. Although Turkey has implemented remarkable reforms in TVET, it still needs to gain attractiveness by students, as successful students prefer to go general high schools (Gelişli et al. 2016). It could be inferred that even if teachers do their best, they are struggling with gaining demoralised and structurally excluded students because of the social inequalities inherent to socio-cultural positioning of vocational high schooling in the society. Thus, to empower the teachers through new curricula approaches could move some way to redress student esteem, the esteem of vocational high schooling and reseeding social justice for TVET. In practice, the results implied 
that career practitioners should go beyond of counselling with students, only and consider enlarging their practices towards broader context and systems such as schools and working environments (Hartung and Blustein 2002). In this sense, career practitioners should collaborate with school and other partners to develop strategies to overcome these problems by responding school ecology and culture (Nastasi et al. 2000). Finally, the findings suggested the research could focus on social justice issues in TVET by reaching out not only teachers, but also to students, parents, even the society. Further research could perform a participatory action research to implement solutions for challenges and problems that teachers confront in a vocational high school from socioeconomically disadvantaged locations, and evaluate the process and outcomes, as well. This would answer the questions of how social justice could be integrated into career practices (e.g., Arthur et al. 2009; Irving 2005).

\section{Disclosure statement}

No potential conflict of interest was reported by the authors.

\section{ORCID}

Ahmet Ayaz (D) http://orcid.org/0000-0002-4081-2033

Nurten Karacan Özdemir (D) http://orcid.org/0000-0002-2909-6857

\section{References}

Abdullah, R. N., R. A. I. R. Yaacob, A. J. C. M. Hashim, I. A. Hussain, and A. Roslan. 2019. "Intensifying Experiential Learning with Dynamic Learning Styles in Traditional Classroom for Technical and Vocational Students." Journal of Technical Education and Training 11 (4): 1-10. doi:10.30880/jtet.2019.11.04.001.

Alcock, P. 1997. Understanding Poverty. New York: Macmillan International Higher Education. Ali, A., and H. Marwan. 2019. "Exploring Career Management Competencies in Work Based Learning (WBL) Implementation." Journal of Technical Education and Training 11 (1): 159-166. doi:10.30880/jtet.2019.11.01.020.

American Management Association (AMA). 2019. "Executives Say 21st Century Needs More Skilled Workers.". Accessed 13 January 2020. https://www.amanet.org/articles/executivessay-21st-century-needs-more-skilled-workers/

Arthur, N. 2005. "Building from Diversity to Social Justice Competencies in International Standards for Career Development Practitioners." International Journal for Educational and Vocational Guidance 5 (2): 137-148. doi:10.1007/s10775-005-8791-4.

Arthur, N., and M. McMahon. 2005. "Multicultural Career Counseling: Theoretical Applications of the Systems Theory Framework." The Career Development Quarterly 53 (3): 208-222. doi:10.1002/j.2161-0045.2005.tb00991.x.

Arthur, N., S. Collins, M. McMahon, and C. Marshall. 2009. "Career Practitioners' Views of Social Justice and Barriers for Practice." Canadian Journal of Career Development 8 (1): 22-31. 
Avşaroğlu, S., M. E. Deniz, and A. Kahraman. 2005. "Investigation of Life Satisfaction, Job Satisfaction and Professional Burnout Levels in Technical Teachers." Selçuk University Journal of Social Sciences Institue 14: 115-129.

Ayonmike, C. S., P. C. Okwelle, and B. C. Okeke. 2015. "Towards Quality Technical Vocational Education and Training (TVET) Programmes in Nigeria: Challenges and Improvement Strategies." Journal of Education and Learning 4 (1): 25-34. doi:10.5539/jel.v4n1p25.

Benešová,, and Tupa, 2017. "Requirements for Education and Qualification of People in Industry 4.0". Paper presented at the annual meeting for the 7th International Conference on Flexible Automation and Intelligent Manufacturing, FAIM2017, Modena, June 2195-2202. doi: 10.1016/j.promfg.2017.07.366.

Bishop, J. H., and F. Mane. 2004. "The Impacts of Career-Technical Education on High School Labor Market Success." Economics of Education Review 23 (4): 381-402. doi:10.1016/j. econedurev.2004.04.001.

Boesel, D., and L. McFarland 1994. "Final Report to Congress (Vol. 1). Office of Educational Research and Improvement, US Department of Education," National Assessment of Vocational Education.

Bottoms, G., and K. McNally 2005. “Actions States Can Take to Place a Highly Qualified Career/ technical Teacher in Every Classroom." Accessed 13 January 2020. https://www.sreb.org/ publication/actions-states-can-take-place-highly-qualified-careertechnical-teacher-everyclassroom

Bozgeyikli, H. 2019. "Mesleki Ve Teknik Eğitimin Geleceği." Accessed 31 August 2020. https:// ilke.org.tr/images/yayin/pdf/meleki-egitimin-gelecegi.pdf

Buthelezi, Z. 2018. "Lecturer Experiences of TVET College Challenges in the Post-Apartheid Era: A Case of Unintended Consequences of Educational Reform in South Africa." Journal of Vocational Education and Training 70 (3): 364-383. doi:10.1080/13636820.2018.1437062.

Carlisle, L. R., B. W. Jackson, and A. George. 2006. "Principles of Social Justice Education: The Social Justice Education in Schools Project." Equity \& Excellence in Education 39 (1): 55-64. doi:10.1080/10665680500478809.

Çınar, H., N. Döngel, and C. Söğütlü. 2009. "A Case Study of Technical and Vocational Education in Turkey." Procedia - Social and Behavioral Sciences 1 (1): 160-167. doi:10.1016/j.sbspro.2009.01.030.

Çiçek Sağlam, A., and N. Dönmez. 2016. "The Causes of the Students' Absenteeism Invocational High Schools and the Opinions of Principles' and Teachers' on the Possible Solutions." Journal of Contemporary Administrative Science 3 (1): 1-9.

Çavuşoğlu, D., and A. C. Savaş. 2016. "The Problems that the Culture Course Teachers Working at Vocational High Schools Face and the Solution Proposals to Those Problems (A Case Study of Pazarcık District)." Journal of Contemporary Administrative Science 3 (1): 1-13.

Creswell, J. W. 2012. Educational Research: Planning, Conducting, and Evaluating Quantitative. 4th ed. New Jersey: Pearson.

Dağ, A. 2018. "A Qualitative Research on School Orientation Processes of Vocational and Technical Anatolian High School Students." International Journal of Turkish Literature Culture Education 7 (3): 1995-2012. doi:10.7884/teke.4293.

Dania, J., A. R. Bakar, and S. Mohamed. 2014. "Factors Influencing the Acquisition of Employability Skills by Students of Selected Technical Secondary School in Malaysia." International Education Studies 7 (2): 117-124. doi:10.5539/ies.v7n2p117.

Egun, A. C., and E. U. Tibi. 2010. "The Gender Gap in Vocational Education: Increasing Girls Access in the 21 St Century in the Midwestern States of Nigeria." International Journal of Vocational and Technical Education 2 (2): 18-21. doi:10.1177/0019793914564963.

European Center for the Development of Vocational Training (Cedefop). 2019. "Turkey European Inventory on NQF 2018." Accessed 1 September 2020. https://www.cedefop. 
europa.eu/en/publications-and-resources/country-reports/turkey-european-inventorynqf-2018

Gall, M. D., J. P. Gall, and W. R. Borg. 2014. Applying Educational Research: How to Read, Do, and Use Research to Solve Problems of Practice. New York: Pearson Higher Ed.

Garisch, C. 2007. SESD II Evaluation Mthashana Fet College Pretoria. Pretoria: Human Sciences Research Council Press.

Gautam, S., T. Poudel, and P. K. Paudel. 2018. "Technical and Vocational Education for Social Transformation and Justice." Journal of Education and Research 8 (1): 1-5. doi:10.3126/jer. v8i1.25474.

Gelişli, Y., L. Beisenbayeva, Z. M. Sultanbek, and A. Ussenova. 2016. "Vocational Education Systems in Turkey and the World: New Trends and Problems." International Journal on New Trends in Education and Their Implications 7 (3): 1-10.

Girgin, S., and T. Demir. 2017. "Perceptions of Vocational High School Teachers about the Quality of Business Life." The Journal of Academic Social Science Science 5 (56): 555-572. doi:10.16992/ASOS.12811.

Grollmann, P. 2008. "The Quality of Vocational Teachers: Teacher Education, Institutional Roles and Professional Reality." European Educational Research Journal 7 (4): 535-547. doi:10.2304/eerj.2008.7.4.535.

Hackman, H. W. 2005. "Five Essential Components for Social Justice Education." Equity \& Excellence in Education 38 (2): 103-109. doi:10.1080/10665680590935034.

Hartung, P. J., and D. L. Blustein. 2002. "Reason, Intuition, and Social Justice: Elaborating on Parsons's Career Decision-Making Model." Journal of Counseling and Development 80 (1): 41-47. doi:10.1002/j.1556-6678.2002.tb00164.x.

Hassan, R. 2010. "Strengthening Technical and Vocational Education (TVET) - Producing Innovative TVET Teachers for 21st Century Students." Paper presented at the annual meeting for the 2nd World Congress on Teacher Education for TVET, 5-6 October University of Tun Hussein Onn: Malaysia.

Hawke, G. 2000. "Implications for Vocational Education and Training of Changing Work Arrangements." Working paper. ERIC database. (ED454436)

Hayward, G. C., and C. S. Benson. 1993. Vocational-Technical Education: Major Reforms and Debates 1917-Present. Washington, DC: Office of Vocational and Adult Education. U.S. Department of Education. ERIC database. (ED3699598).

Hooley, T., and R. Sultana. 2016. "Career Guidance for Social Justice." Journal of the National Institute for Career Education and Counselling 36 (1): 2-11. doi:10.20856/jnicec.3601.

Hytten, K., and S. C. Bettez. 2011. "Understanding Education for Social Justice." The Journal of Educational Foundations 25: 7-24.

International Centre for Technical and Vocational Education and Training (UNECOV). 2013. "World TVET Database Turkey."Accessed 6 December 2019. https://unevoc.unesco.org/ wtdb/worldtvetdatabase_tur_en.pdf

Irving, B. A. 2005. "Social Justice: A Context for Career Education and Guidance." In Critical Reflections On Career Education And Guidance: Promoting Social Justice Within A Global Economy Abingdon, edited by B. A. Irving and B. Malik, 10-24. Oxon: Routledge Farmer.

Ismail, A., and N. Z. Abiddin. 2014. "Issues and Challenges of Technical and Vocational Education and Training in Malaysia Towards Human Capital Development." Middle-East Journal of Scientific Research 19 (2): 7-11. doi:10.5829/idosi.mejsr.2014.19.icmrp.2.

Ismail, A. A., and R. Hassan. 2019. "Technical Competencies in Digital Technology Towards Industrial Revolution 4.0.." Journal of Technical Education and Training 11 (3): 55-62. doi:10.30880/jtet.2019.11.03.008.

Ismail, M. E., S. Hashim, N. Abd Samad, N. Hamzah, S. H. Masran, K. A. Mat Daud, N. F. Amin, M. A. Samsudin, and N. Kamarudin. 2019. “Factors that Influence Students' Learning: An 
Observation on Vocational College Students." Journal of Technical Education and Training 11 (1): 93-99. doi:10.30880/jtet.2019.11.01.012.

Jacques, C., and A. Potemski 2014. "21st Century Educators: Developing and Supporting Great Career and Technical Education Teachers. Special Issues Brief. Revised Edition." Accessed 18 January 2020. https://gtlcenter.org/products-resources/21st-century-educatorsdeveloping-and-supporting-great-career-and-technical

Karacan-Ozdemir, N., and A. Ayaz. 2020. "School Counseling and Guidance Programs: Examination of Career Adaptabilities." Hacettepe University Journal of Education 35 (3): 613-626. doi:10.16986/HUJE.2018045437.

Kennedy, G. W., U. S. Udoetuk, and S. I. Ufot. 2017. "Challenges of Technical Vocational Teacher Education and Teaching in Nigeria: The Need for Intervention." International Journal of Education and Evaluation 3 (7): 71-82.

Kim, W., H. Y. Shin, H. Woo, and J. Kim. 2019. "Further Training Needs for TVET Trainers: Lessons from A National Survey on Rwandan TVET Trainers' Instructional Competencies." Journal of Technical Education and Training 11 (2): 32-45. doi:10.30880/jtet.2019.11.02.004.

Lamb, S. 2011. "TVET and the Poor: Challenges and Possibilities." International Journal of Training Research 9 (1-2): 60-71. doi:10.5172/ijtr.9.1-2.60.

Lewis, T. (1998). "Toward the 21st Century: Retrospect, Prospect for American Vocationalism." ERIC database. (ED423421).

Lynch, R. 2000. "High School Career and Technical Education for the First Decade of the 21st Century." Journal of Vocational Education Research 25 (2): 155-198. https://scholar.lib.vt. edu/ejournals/JVER/v25n2/lynch.html

Lynch, R. L. 1997. "Designing Vocational and Technical Teacher Education for the 21st Century: Implications from the Reform Literature. ERIC Clearinghouse on Adult, Career, and Vocational Education." Center on Education and Training for Employment, College of Education, the Ohio State University.

Merriam, S. B. 1998. Qualitative Research and Case Study Applications in Education. 2nd Revised and Expanded Edition. San Francisco: Jossey-Bass Publishers.

Miles, M. B., and M. Huberman. 1994. Qualitative Data Analysis: An Expanded Sourcebook. 2.nd ed ed. California: Sage.

Miller, D. 2001. Principles of Social Justice. Cambridge: Harvard University Press.

Miller, M. D. 1984. Principles and A Philosophy for Vocational Education. Eric Database. (ED250497). Washington DC: Office of Vocational and Adult Education.

Mohamad, M. M., M. S. Saud, and A. Ahmad. 2009. "The Need in Training and Retraining for TVET Teachers in Malaysia." Journal of Technical Education and Training 1 (1): 51-57.

Murgor, T. K. 2013. "Relationship between Technical and Vocational Acquired Skills and Skills Required in Job Market; Evidence from TVET Institutions, Uasin Gishu County, Kenya." Journal of Education and Practice 4 (19): 77-84.

Nastasi, B. K., K. Varjas, R. Bernstein, and A. Jayasena. 2000. "Conducting Participatory Culture-Specific Consultation: A Global Perspective on Multicultural Consultation." School Psychology Review 29 (3): 401-413. doi:10.1080/02796015.2000.12086024.

National Association of Colleges and Employers (NACE). 2017. "The Key Attributes Employers Seek on Students' Resumes." Accessed 3 February 2020. https://www.naceweb.org/about-us /press/2017/the-key-attributes-employers-seek-on-students-resumes/

National Board for Professional Teaching Standards (NBPTS). 2017. "Early Adolescence through Young Adulthood/career and Technical Education." Accessed 14 December 2019. http://www.nbpts.org/wp-content/uploads/EAYA_CTE_Component1.pdf

Nussbaum, M. C. 2011. Creating Capabilities. Cambridge: Harvard University Press.

OECD. 2010. "Learning for Jobs". Accessed 26 January 2020. http://www.oecd.org/education/ skills-beyondschool/Learning\%20for\%20Jobs\%20book.pdf 
Oketch, M. O. 2007. "To Vocationalise or Not to Vocationalise? Perspectives on Current Trends and Issues in Technical and Vocational Education and Training (TVET) in Africa.." International Journal of Educational Development 27 (2): 220-234. doi:10.1016/j. ijedudev.2006.07.004.

Omar, M. K., A. M. Rashid, M. Hazwan, M. Puad, and J. Satisfaction. 2019. "What Makes Me Stay in Teaching ?" Exploring Retention Factors of TVET Teachers in Malaysia." International Journal of Advanced Science and Technology 28 (8): 130-139.

Özer, M. 2018. "2023 Eğitim Vizyonu Ve Mesleki Ve Teknik Eğitimde Yeni Hedefler." Journal of Higher Education and Science 8 (3): 425-435. doi:10.5961/jhes.2018.284.

Özer, M. 2019. "Reconsidering the Fundamental Problems of Vocational Education and Training in Turkey and Proposed Solutions for Restructuring." Istanbul University Journal of Sociology 39 (2): 455-473. doi:10.26650/SJ.2019.39.2.0098.

Patton, M. Q. 2014. Qualitative Research and Evaluation Methods: Integrating Theory and Practice. 4th. ed. Los Angles: Sage Publications.

Peker, A., and C. Kaygusuz. 2009. "Investigation of Expectation Levels of Students, Teachers and Administrators in General and Vocational High Schools from Psychological Counseling and Guidance Services." Sakarya University Journal of Education Faculty 17: 96-110.

Pfeiffer, T. 2015. "Next Generation Mobile Fronthaul and Midhaul Architectures." Journal of Optical Communications and Networking 7 (11): 38-45. doi:10.1364/JOCN.7.000B38.

Plank, S. B., S. DeLuca, and A. Estacion. 2008. "High School Dropout and the Role of Career and Technical Education: A Survival Analysis of Surviving High School." Sociology of Education 81 (4): 345-370. doi:10.1177/003804070808100402.

Raymond, E., E. M. Uduafemhe, S. A. Alome, and B. A. O. Ogumah. 2018. “Correlation between the Five Personality Dimensions and Creative Behaviours of Electrical and Electronics Teachers in Nigerian Technical Colleges." Journal of Technical Education and Training 10 (2): 28-37. doi:10.30880/jtet.2018.10.02.003.

Republic of Turkey Ministry of Industry and Technology. 2018. "Turkey's Industrial Revolution "Digital Turkey" Road Map." Accessed 26 November 2019. https://www.gmka.gov.tr/doku manlar/yayinlar/2023_Dijital-Turkiye-Yol-Haritasi.pdf

Resh, N., and C. Sabbagh. 2016. "Justice and Education." In Handbook of Justice Theory and Research, edited by C. Sabbagh and M. Schmitt, 349-368. New York: Springer.

Rojewski, J. W. 2002. "Preparing the Workforce of Tomorrow: A Conceptual Framework for Career and Technical Education." Journal of Vocational Education Research 27 (1): 7-35. doi:10.5328/jver27.1.7.

Sahlberg, P. 2007. "Secondary Education in OECD Countries: Common Challenges, Differing Solutions". Accessed 4 December 2020. https://www.etf.europa.eu/sites/default/files/m/ C12578310056925BC12573850034415B_NOTE78HD6G.pdf

Sarkees-Wircenski, M., and J. L. Scott. 1995. Vocational Special Needs. 3 rd. ed. Illinois: American Technical Publishers.

Sen, A. 1999. Development as Freedom. New York: Oxford University Press.

Sen, A. K. 2009. The Idea of Justice. Cambridge: Harvard University Press.

Spöttll, G. 2009. "Teacher Education for TVET in Europe and Asia: The Comprehensive Requirements." Journal of Technical Education and Training 1 (1): 1-16.

Taş, A., A. Selvitopu, V. Bora, and Y. Demirkaya. 2013. "Meslek Lisesi Öğrencilerinin Okul Terk Nedenleri." Kuram Ve Uygulamada Egitim Bilimleri 13 (3): 1551-1566. doi:10.12738/ estp.2013.3.1398.

Tamer, M. A., and M. Özcan. 2014. "Evaluation of the Organizational Vocational and Technical Education System by the Stakeholders of Vocational Education." Journal of National Education 44 (203): 205-224. 
Toytok, E. H., and M. B. Yıldırım. 2018. "Disciplinary Problems and Causes of Vocational High Schools." Abant Izzet Baysal University Journal of Education Faculty 18 (3): 1759-1778. doi:10.17240/aibuefd.2018.18.39790-439030.

Tunç, B., S. Yıldız, and A. Doğan. 2015. "Discipline Problems in Vocational High School, Causes and Solutions: A Case Study." Abant Izzet Baysal University Journal of Education Faculty 15 (2): 384-403. doi:10.17240/aibuefd.2015.15.2-5000161330.

Turkish Ministry of National Education (MoNE). 2018a. "View of Vocational and Technical Education in Turkey." Accessed 4 January 2020. https://mtegm.meb.gov.tr/meb_iys_dosya lar/2018_11/12134429_No1_Turkiyede_Mesleki_ve_Teknik_Egitimin_Gorunumu.pdf

Turkish Ministry of National Education (MoNE). 2018b. "Educational Vision of 2023." Accessed 6 December 2019. http://2023vizyonu.meb.gov.tr/doc/2023_EGITIM_VIZYONU.pdf

Turkish Ministry of National Education (MoNE). 2019. "Vocational and Technical Education in Organized Industrial Zones." Accessed 4 February 2020. https://www.meb.gov.tr/meb_iys_ dosyalar/2019_06/12103640_2019_06_12_Organize_Sanayi_Bolgelerinde_Mesleki_ve_ Teknik_Egitim.pdf

Turkish Republic Presidential Strategy and Budget. 2019. "Eleventh Development Plan (2019-2023)." Accessed 02 January 2020. http://www.sbb.gov.tr/wp-content/uploads/ 2019/07/OnbirinciKalkinmaPlani.pdf

United Nations Educational, Scientific and Cultural Organization (UNESCO). 2012. "The International Standard Classification of Education (ISCED)." Accessed 21 November 2019. http://uis.unesco.org/sites/default/files/documents/international-standard-classificationof-education-isced-2011-en.pdf

Vandekinderen, C., G. Roets, H. Van Keer, and R. Roose. 2018. "Tackling Social Inequality and Exclusion in Education: From Human Capital to Capabilities." International Journal of Inclusive Education 22 (1): 1-20. doi:10.1080/13603116.2017.1362044.

Viviano, T. 2012. "What 21st Century Leadership in Career and Technical Education Should Look Like." Journal of Career and Technical Education 27 (2): 51-56. doi:10.21061/jcte. v27i2.559.

Wheelahan, L., and G. Moodie 2016. "Global Trends in TVET: A Framework for Social Justice." Accessed 9 January 2020 https://www.ei-ie.org/media_gallery/GlobalTrendsinTVET.pdf Yıldııı, A., and H. Şimşek. 2016. Qualitative Research Methods. Ankara: Seçkin Publication.

Yin, R. K. 2018. Case Study Research and Applications: Design and Methods. 6th. ed. Los Angles: Sage Publications.

Zulu, W. V., and S. Mutereko. 2020. "Exploring the Causes of Student Attrition in South African TVET Colleges: A Case of One Kwazulu-Natal Technical and Vocational Education and Training College." Interchange. 10.1007/s10780-019-09384-y. 